\title{
SUSTAINING ASSOCIATES
}

The Israeli Phytopathological Society

\author{
Isaac Federman Ltd. \\ Luxembourg Chemicals and Agriculture Ltd. \\ Tapazol Chemical Works Ltd.
}

\section{CORRECTION}

In the article by G. Kritzman and Y. Ben-Yephet, "Control by metham-sodium of Xanthomonas campestris pv. campestris and the pathogen's survival in soil," Phytoparasitica 18(3):217-227 (1990), the amount of metham-sodium applied per kilogram of soil should be 100 times less than published, viz., 0.04, 0.08, 0.12 and $0.16 \mathrm{ml} / \mathrm{kg}$ soil, instead of $4,8,12$ and $16 \mathrm{ml} / \mathrm{kg}$ soil, respectively. Please correct accordingly on p. $217,1.7$; p. $220,1.24$ and 1. 36; p. 221, last line; p. 222, 1.1 and 1 . 2; p. 223, Table 3, first column; and p. 224, Table 4, footnote $z$. 